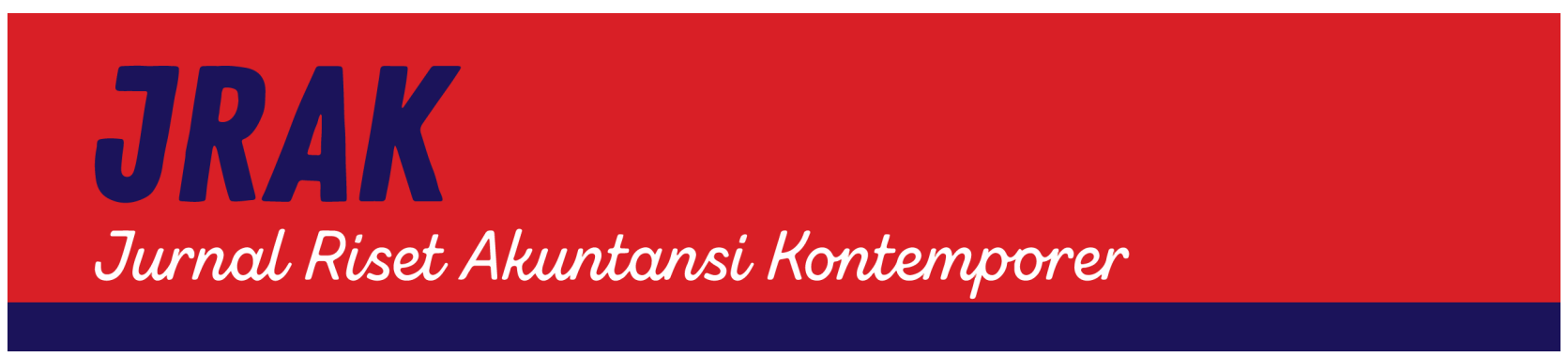

\title{
FIRM CHARACTERISTICS AND EARNINGS MANAGEMENT IN LISTED SINGAPOREAN CORPORATIONS
}

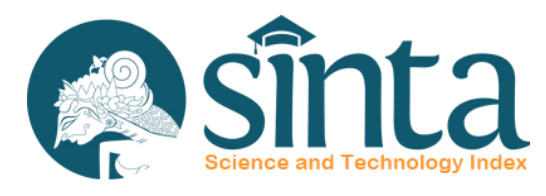

https://journal.unpas.ac.id/index.php/jrak/index

\author{
Efva O. D. Gozali ${ }^{1} \bowtie$, Ruth S. Hamzah ${ }^{2}$, Chomsah N. Pratiwi ${ }^{3}$, Marissa Octari ${ }^{4}$ \\ ${ }_{1,2,3,4}$ Universitas Sriwijaya \\ $\triangle$ efvagozali@unsri.ac.id \\ Jl. Masjid Al Gazali, Bukit Lama, Kota Palembang, Sumatera Selatan,Indonesia
}

\section{Article Info}

History of Article

Received: 7/6/2021

Revised: 8/8/2021

Published: 18/10/2021

Jurnal Riset Akuntansi Kontemporer

Volume 13, No. 2, October 2021, Page 72-81

ISSN 2088-5091 (Print)

ISSN 2597-6826 (Online)

Keywords: earnings management; firm age; firm size; leverage; profitability

\begin{abstract}
The study aims to examine the association of firms characteristics comprise of firm age, firm size, leverage, and profitability to earnings management (EM). The data is collected from listed Singaporean corporation in Singapore stock exchange (SGX) in the period of 2017 and 2018. Purposive sampling and panel data regression were employed as the sampling and analysis method, respectively. Our results are based on a large sample of 852 firm-year observations. The results show that firm age and firm size significantly affected EM, meanwhile, leverage and profitability indicate insignificant effects to EM. In addition, these results provide information to investors and potential investors regarding future investment decisions.
\end{abstract}

\section{INTRODUCTION}

The financial report is a communication tool to provide financial information for related or third parties. It describes the result of operational activities and performance carried out by the company to be reported to internal and external parties with the parameter is in the form of profit or earning (Hasty et al., 2017). This earnings information can be used for internal and external parties to make decisions, therefore the quality of earnings is very attractive and is of concern to various groups, including investors, creditors and accounting policy makers, as well as the government, namely the Directorate General of Taxes (Permatasari and Wulandari, 2021). The profit presented in financial report is one of the benchmarks for either a company has experienced an increase or decrease in earnings (Tampubolon 2015). Earning is a measurement of a company's performance summary based on accrual-based accounting (Agustia and Suryani, 2018). However, information regarding earnings is sometimes inaccurate because earnings information is often misused by management in order to fulfill their satisfaction or personal interests (Astuti et al., 2017). This is also due to the tendency of those who pay attention to earnings and are recognized by management, particularly managers whose performance is measured based on earnings information. Thus, encouraging the emergence of an action to manage earnings or commonly known as earnings management (EM) (Savitri 2014).

EM is an act of manipulating earnings through the intervention of a manager in external financial reporting for personal gain (Padli et al., 2019). EM occurs when management changes the financial statements to affect 
contractual results and transactions that rely on reported accounting numbers. EM is a serious problem because this behavior impairs the economic, ethical and moral order (Firnanti, 2018). EM is also able to reduce the credibility of financial statements because they do not reflect the actual condition of the company (Alami 2021). EM is the behavior of managers to manipulate stakeholders for personal interest (Utrero-González and J. Callado-Muñoz 2016). EM is divided into two, namely real EM and accrual EM. Research conducted by Liu (2015) stated that many managers prefer real EM over accrual EM. However, according to Herlambang et al. (2015), accrual EM outperforms real EM because it considers the problem of time. Therefore, many previous studies have used the accrual approach to measure EM (Dechow et al., 1995; Indriastuti 2012). The goal of EM is to increase or reduce earnings in the long term for economic benefits. The use accrual EM by changing the accounting method to other alternative accounting methods to exaggerating earnings (Senjani 2013).

In 1997 there was a noteworthy crisis in Singapore which disrupted the economic growth, it affected management behavior to avoid reporting negative income growth by engaging in EM (Dichev 1997). Different firms of corporate governance between Asian companies such as Singapore and advanced countries such as the United States can affect the level of EM (Charoenwong and Jiraporn, 2009). Singapore also provides an important setting for examining the relationship between EM and auditor quality, which can detect EM (Rusmin 2010). According to research conducted by Leuz (2003), Singapore has a more pervasive management income than the United States, therefore Singapore can improve the quality and reporting of corporate earnings. According to the IFRI Center for Asian Study, Singapore provides foreign investment (FDI) of $45 \%$ in ASEAN and becomes a benchmark for capital markets in Asia (CNBC Indonesia, 2020).

The theoretical framework used in this study is agency theory where if management has more information than the principal or there is an information imbalance between shareholders and management, it will create opportunities for EM (Panjaitan and Muslih. 2019). Agency theory is an issue that occurs between agent and principal due to different interests (Solomon et al. 2021). Meanwhile, according to Panjaitan and Muslih (2019) agency theory is a contract between one or more principals and agents. First, agency problems occur when share ownership is dispersed so that shareholders cannot control the manager, second if the majority shareholders are able to control management (Hasty et al. 2017). The asymmetry of interest or information between the principal and the agent encourages the agent to present disinformation to the principal, one form of the action of agent is EM (Widyawati and Anggraita, 2013).

This study develops previous research conducted by Mendes et al., (2012) by analyzing a specific strategy of EM, smoothing income in firms listed on Euronext Lisbon which aims to reduce the variability of earnings over time in order to achieve long-term goals. Several limitations in this previous study made researchers motivated to do this research, one of them, first in terms of the sample that still has to be expanded where we take a different sample, i.e., Singapore Stock Exchange. Moreover, the differences from the results of previous studies regarding the factors that influence EM practices also provide motivation for researchers to review the factors that can affect EM.

Several factors indicate EM within an organization, including the firm age, firm size, leverage and profitability (Agustia and Suryani, 2018). A firm that has been established or has been operating for a long time usually discloses information about the social and environmental information of the firm, in order to improve the image in the community (Badulescu et al. 2018; Nidheesh 2020). Firm age is a used to measure the effect of how long the firm operates on firm performance. The firm age shows whether the company will continue to exist, be able to compete and take advantage of business opportunities in the economy (Savitri 2014). In research conducted by Debnath (2017) and Agustia and Suryani (2018) states that firm age has an effect on EM. The firm age shows the ability of how long a company has been in competitiveness. Furthermore, the longer firm age, the more experience it has in managing and increasing profits compared to firms that newly established (Zen and Herman 2007). Meanwhile, according to the research of Bassiouny (2016) and Fajari (2020), firm age has no effect on EM. Newly established firms tend to perform EM than that of old firms. According to research Agustia and Suryani (2018), firm age has an effect on EM. Meanwhile, research by Chandra et al. (2018) states that firm age has no effect on EM.

Firm size is a scale that can be classified as large and small as a company in various ways, such as total assets, log size, sales and market capitalization (Agustia and Suryani, 2018). This can be seen from the research conducted Azlina (2010) stated that firm size has an effect on EM. Meanwhile, research by Wardani and Isbela (2017) indicates that firm size has no effect on EM. The firm size is a benchmark for investors in making their investments. The firm size will greatly affect the practice of EM because a larger firm must be able to meet the expectations of investors and shareholders, this tends to make firm engages in EM (Astuti et al. 2017). Research conducted by Gunawan et al. (2015) and Agustia and Suryani (2018) stated that firm size has no effect on EM. In fact, since firm size is not the only indicator in making decisions yet investors should consider the other determinant factors in detecting EM. Meanwhile, according to research conducted 
by Yuliana et al. (2015) and Octavia (2017) show the influence of firm size on EM. The bigger firm, the greater opportunity to carry out EM if the supervision is low (Yuliana et al. 2015). Large firms are more careful to be trusted in presenting accurate financial reports, while small companies tend to carry out EM activities to show satisfactory financial performance (Octavia 2017).

Leverage is the firm's ability to meet all financial obligations consisting of long and short term debt, which is measured by Debt to Equity Ratio (DER) (Jariah 2016). According to research Eva and Yasa (2020), leverage affects EM significantly. However, according to research of Chandra et al. (2018), leverage has no effect on EM. Leverage is used to measure the size of the firm financed by debt. The use of leverage aims to obtain greater profits than the assets or sources of funds, it provides benefits for shareholders (Agustia and Suryani, 2018). A company that has a high level of leverage is more likely to allow the firm to violate credit agreements (Carolina 2021). The goal is to increase the profits earned is greater than the amount of assets and funds (Harjito and Martono 2014). Research conducted by Titik et al. (2014) and Agustia (2013) state that leverage has an effect on EM. The results of both studies show that the greater leverage, the higher debt, thus it tends to manipulate in the form of EM. The similar result is revealed by Mahawyahrti and Budiasih (2016) and Astuti et al., (2017) which found that leverage has an effect on EM. A condition of firm with a large level of leverage makes a dependency on external parties which resulted firm prefers to pay debt. Further, management engage in EM activity to increase the revenue (Astuti et al. 2017; Octavia 2017).

Profitability shows the financial achievement of the firm, which is proxied by Return On Assets (ROA) (Utari and Amin, 2011). The higher ROA, the more efficient assets usage in order to increase profits (Desender et al., 2011). According to the research by Maryana and Carolina, (2021) which states that profitability has an effect on EM, while according to Wardani and Isbela (2017), profitability has no effect on EM. Profitability is a ratio to indicate financial performance ability in a firm. The profitability ratio provides a measure of the level of management effectiveness in a firm (Agustia and Suryani, 2018). Firms that have a high level of profitability will show that the firms are in good condition and vice versa, if the profits generated are small, it indicates that the firm is not financially stable (Prawida 2021). Profitability is able to measure the level of effectiveness in management (Cashmere 2012). Research conducted Amertha (2013) and Hasty et al. (2017) state that profitability has an effect on EM which aims to appear good performance. If the profitability is high, the firm value is high. In line previous study conducted by Purnama (2017) which states that profitability has an effect on EM, corresponding to bonuses that management will be received are low if the profitability is low. It causes management engaged in EM in order to receive higher bonus (Purnama 2017).

Therefore, the research scope is to determine the effect of company age, company size, leverage, and profitability on EM. The samples obtained from listed firms on the Singapore Stock Exchange (SGX) in 2017-2018. This study provides benefits for internal parties in indicating earnings management practices. For external parties, namely investors, potential investors and stakeholders, this study can provide information for making decisions regarding future investments. In addition, this research also contributes to the company to reduce the variability of earnings over time which causes EM possibility to occur.

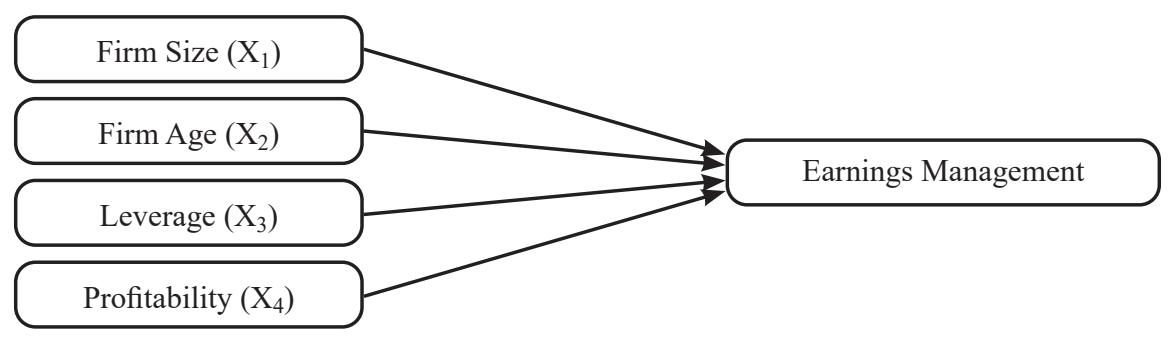

Figure 1. Research Framework

\section{METHOD}

Descriptive quantitative is used as the data analysis method. The samples are obtained from listed firms on the Singapore Stock Exchange (SGX) in 2017-2018. The dependent variable of this study is EM. EM is a manager's decision to manipulate financial reports for personal groups benefit (Prawida 2021). The existence of information asymmetry and the tendency of external parties (investors) to pay more attention to firm profits as a measure of performance, encourages management to manipulate in presenting earnings information, it is called EM (Agustia 2013). EM in this study is measured using Total Accrual (TAC) with the following formula (Mendes et al. 2012) : 


\section{$\mathrm{TAC}=$ Net Income - Total Cash Flow}

The size of the company in this study is measured by total assets or total sales (Padli et al. 2019). Greater the total assets shows the greater the size of a firm. The measurement of total assets is formulated as follows:

$$
\text { Company Size }=\text { Ln }(\text { Total Asset })
$$

Firm age is the length of time a firm has been established. Firms that have been established for a long time are assumed to be able to generate higher profits compared to newly established Firms. A long-established firm will endeavor to increase profits, due to the experience of previous management. This will encourage the firm to do EM by reducing the risk of fluctuations in profits with high growth, thus the company will engage in EM (Indracahya and Faisol 2017). In this study, firm age is measured by the following formula:

$$
\text { Firm age }=\text { Year of research }- \text { Year of firm establishment }
$$

Leverage is the efforts to increase firm profits which can be one of the benchmarks for management to perform EM. Firms that have a high level of leverage are suspected of carrying out EM because the firm is

$$
\text { Debt to Equity Ratio }(\mathrm{DER})=\frac{\text { Total Liabilities }}{\text { Total Equity }} \times 100 \%
$$

threatened with default, that is, it cannot fulfill its obligations to pay debts on time (Mahawyahrti and Budiasih 2016). In this study, leverage is proxied to the Debt to Equity Ratio (DER) which is formulated as follows:

Profitability is the final result of a firm in selling its products to the market. The level of profitability of a firm can reflect the financial condition. Firms with a high level of profitability will show that they are

$$
\text { Return on Assets (ROA) }=\frac{\text { Profit After Tax }}{\text { Total Asset }} \times 100 \%
$$

considerably in a good condition, meanwhile firms with a low level of profitability indicate poor performance (Prawida 2021). In this study, profitability is proxied by Return on Assets (ROA), with the following formula:

The population in this study is listed firms on SGX circa 2017-2018. Singapore was chosen as object due to it is a benchmark for the capital market in Southeast Asia, based on a study by the IFRI Center for Asian Study since 1990, Singapore's foreign investment (FDI) has contributed 45\% of the total FDI in ASEAN (CNBC Indonesia, 2020). Singapore is also a country with the highest transactions in Southeast Asia and included in the 10 countries in the world with the most active capital markets, according to the Institute for Management Development (IMD), strong technology infrastructure (ekonomibisnis.com 2020). Before the COVID-19 pandemic occurred, in 2017 and 2018 financial conditions around the world were relatively stable, particularly in Singapore where the currency was not affected by inflation. According to preliminary data from the Singapore Ministry of Trade in 2018 gross domestic product (GDP) rose by $2.8 \%$ and it has been recorded that since 2017 it has expanded by $3.5 \%$ (ekonomibisnis.com 2018). Purposive sampling was employed to

Table 1. Sampling Criteria

\begin{tabular}{clr}
\hline No. & \multicolumn{1}{c}{ Criteria } & Samples \\
\hline 1. & Firms listed on the Singapore Stock Exchange 2017-2018 & 512 \\
2. & Firms that do not publish financial reports and annual reports consistently during the study year period 2017-2018 & $(32)$ \\
3. & Firms that do not have complete data required in this study during the research period & $(54)$ \\
4. & Firms that meet the criteria & 426 \\
5. & Research period & 2 Years \\
\hline & Total year-observations & 852 \\
\hline
\end{tabular}


determine the samples. Further, we obtained 426 companies as samples which comprise of 852 firm-year observation. The sampling criteria are as follows:

The data used in this study are secondary data derived from financial reports on listed firms on the SGX in 2017-2018, thus it is included as panel data. Therefore, the analysis technique employed is panel data regression. According to Jamaludin et al., (2021) the advantages of panel data are that it provides more information; the data has large variability and reduces collinearity resulting in more efficient predictions; and controls the heterogeneity of unobserved locations.

Panel data regression is divided into three types, namely Common Effect Model (CEM), Fixed Effect Model (FEM) and Random Effect Model (REM). However, the approaches that are often used are FEM and REM. There are three tests conducted to determine the most suitable model, namely the Chow test, Hausman test and $\mathrm{F}$ test. Chow test and $\mathrm{F}$ test are used to determine between the CEM and FEM approaches. Meanwhile, Hausman test is used to determine the approach between FEM and REM. Panel data regression model equation in this research is as follows:

$$
\mathrm{YEM}_{\mathrm{it}}=\alpha+\beta_{1} \mathrm{Size}_{\mathrm{it}}+\beta_{2} \mathrm{Age}_{\mathrm{it}}+\beta_{3} \mathrm{DER}_{\mathrm{it}}+\beta_{4} \mathrm{ROA}_{\mathrm{it}}+\varepsilon
$$

Whereas,

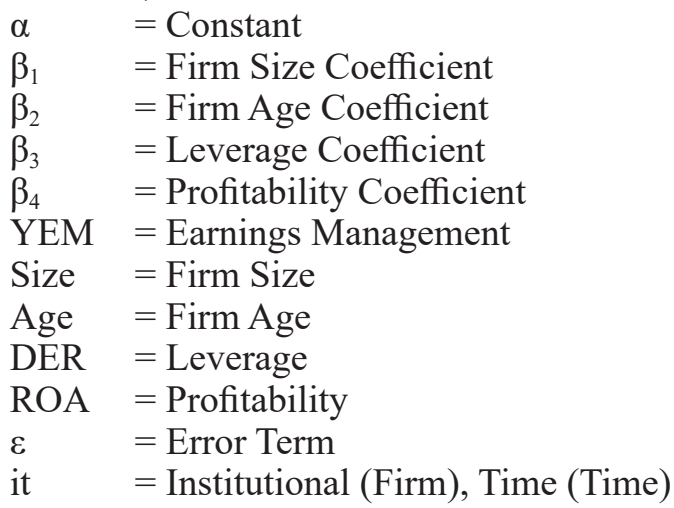

\section{RESULT}

This study employed panel data regression analysis. The samples obtained from listed firms on SGX in 2017-2018 and resulted 852 firm-year observations as samples. Statistical descriptive of samples is shown in Table 2.

Table 2. Descriptive statistics

\begin{tabular}{lccccc}
\hline & EM & Firm Size & Firm Age & Leverage & Profitability \\
\hline Mean & -900143 & 12.66342 & 2.945019 & 181.3548 & 0.584467 \\
Median & -5943 & 12.23924 & 2.995732 & 68.59779 & 2.74 \\
Maximum & 2424894 & 20.32656 & 5.293305 & 44896.46 & 134.78 \\
Minimum & $-7.1 \mathrm{E}+07$ & 5.655992 & 0 & -2953.96 & -141.82 \\
Std. Dev. & 6583290 & 2.198767 & 0.878213 & 1600,353 & 17.33629 \\
Sum & $-7.52 \mathrm{E}+08$ & 10573.96 & 2459,091 & 151431.2 & 488.03 \\
Sum Sq. & & & $2.14 \mathrm{E}+$ & 09 \\
Dev. & $3.61 \mathrm{E}+16$ & 4032,038 & 643.2296 & 09 & 250656.1 \\
\hline
\end{tabular}

Table 2 displays mean, median, minimum, maximum and standard deviation values in order to explain the variables used in the study. Firm size has a minimum value of 5.655992 and a maximum value of 20.32656, with an average value of 12.66342 and a standard deviation value of 2.198767 . Firm age has a minimum value of 0 and a maximum value of 5,293305, with an average value of 2.945019 and a standard deviation of 0.878213 . Furthermore, leverage has a minimum value of -2953.96 and a maximum value of 44896.46 , with an average value of 181.3548 and a standard deviation of 1600,353 . Moreover, Profitability has a minimum value of -141.82 and a maximum value of 134 .

Prior analyses the panel data regression two tests had been conducted, namely the Chow test and the Hausman test. The results of the two tests indicate the Random Effect model (REM) which is the most suitable 
approach used to analyze the data in this study. The advantage of panel data regression is that it allows data to be analyzed without meeting the classical assumption tests. Because in general, panel data has a very large amount of data, thus it often leads to unfulfilled classical assumptions (Ajija et al. 2011). In addition, Gujarati and Porter (2015) explain that the classical assumption test is not required in the REM because the model uses the generalized least square (GLS) method. One of the advantages of the GLS method is that it does not need to fulfill the classical assumption test. The GLS method is believed to overcome the time series autocorrelation and correlation between observations (cross section). The GLS method can also produce an estimator to meet the best linear unbiased estimation (BLUE), which is a treatment method to overcome the violations of the

Table 3. Panel Data Regression Results on Sample Companies at SGX

\begin{tabular}{lcccc}
\hline \multicolumn{1}{c}{ Variable } & Coefficient & Std. Error & t-Statistic & Prob. \\
\hline C & $2.76 \mathrm{E}+08$ & 37372161 & 7.381253 & 0.0000 \\
Firm Size & -24016451 & 2995735. & -8.016881 & 0.0000 \\
Firm Age & 694705.6 & 287355.0 & 2.417587 & 0.0158 \\
Leverage & 290.5962 & 3503,376 & 0.082947 & 0.9339 \\
Profability & 425293.6 & 349680.3 & 1.216235 & 0.2242 \\
R-squared & 0.071152 & Mean dependent var & & -8400978. \\
Adjusted R-squared & 0.066765 & SD dependent var & & $1.46 \mathrm{E}+08$ \\
SE of regression & $1.41 \mathrm{E}+08$ & Sum squared resid & & $1.69 \mathrm{E}+19$ \\
F-statistic & 16,22053 & Durbin-Watson stat & & 1.998921 \\
Prob (F-statistic) & 0.000000 & & & \\
\hline
\end{tabular}

homoscedasticity and autocorrelation assumptions (Gujarati 2015).

Based on table 3, panel data regression analysis equation is formulated which explains the effect of firm size, firm age, leverage, and profitability on EM in firms listed on SGX in 2017-2018, which are as follows:

$$
\mathrm{Y}=2.76 \mathrm{E}+08+(-24016451) \mathrm{X}_{1}+694705.6 \mathrm{X}_{2}+290.5962 \mathrm{X}_{3}+425293.6 \mathrm{X}_{4}+\mathrm{e}
$$

The results of the simultaneous significance test ( $\mathrm{F}$ test) where the probability value (F-statistic) is 0.000000 (Table 2) smaller than the significance value $\alpha=0.05$, thus the independent variables in this study which are firm size, firm age, leverage and profitability simultaneously affect the dependent variable, namely EM in firms listed on the Singapore Stock Exchange in 2017-2018. The results of the partial significance test (t test) show the influence of independent variable individually on dependent variable.

The results of $t$ test indicate firm age and firm size have significant effects on earnings management. Meanwhile, leverage and profitability have no significant effect on earnings management. It is shown in Table 2 , firm size probability value is 0.0000 . The value indicates that 0.0000 smaller than 0.05 , with a negative coefficient of - 2401645. It means that the relationship between the firm size and EM is in the opposite direction, where if the firm size is large, EM decreases, and vice versa. These results indicate that H1 is accepted which is firm size partially has a significant effect on EM. Further, the probability value of the firm age is 0.0158 . The value indicates that 0,0158 smaller than 0.05 with a positive coefficient of 694705.6 , which means that the relationship between the firm age variable is directly proportional, where if the firm age is older, the level of EM increases, and vice versa. The result indicates that $\mathrm{H} 2$ is accepted, where the firm age partially has a significant effect on EM.

Furthermore, the probability value of leverage is 0.9339 , indicating that 0.9339 bigger than 0.05 with a positive coefficient of 290.5962 means that the association of leverage and EM is directly proportional, where if the leverage increases, EM increases either, and vice versa. It indicates that $\mathrm{H} 3$ is rejected, where partially leverage does not have a significant effect on EM. The probability value of profitability is 0.2242 . The value shows that 0.2242 bigger than 0.05 with a positive coefficient of 425293 .6. It means that the relationship between profitability and EM is directly proportional, where if profitability increases, EM will increase either, and vice versa. These results indicate that $\mathrm{H} 4$ is rejected, where partially profitability does not have a significant effect on EM. According to table 2 the amount of Adjusted R square is 0.066765 or 6.6765 percents. It means that earnings management of $6.6765 \%$ is influenced by firm size, firm age, leverage and profitability. Meanwhile, the remaining $93.3235 \%$ is influenced by other factors. 


\section{DISCUSSION}

This study aims to determine the relationship between firm size, firm age, leverage, and profitability on EM. The results of this study indicate that firm age and firm size have a significant effect on EM. Meanwhile, leverage and profitability have no significant effect on EM (Table 2). Firm size has a significant effect on EM, the results of this study are in line with the research of Azlina (2010); Octavia (2017); Yuliana et al. (2015) which state that firm size has a significant effect on EM. This study contrasts with the research of Chandra et al. (2018); Mahawyahrti and Budiasih (2016); Gunawan et al. (2015); Agustia and Suryani (2018) which state that firm size has no significant effect on EM.

The result proves that a larger firm tends to be able to meet the expectations of investors and shareholders. Hence, larger firm is indicated to drive the management to engage in EM to appear good performance in front of investors and shareholders. The firm age variable has a significant effect on EM, the results of this study are in line with the research of Hasty et al. (2017); Hoang et al. (2018); Debnath (2017); Agustia and Suryani (2018) which state that firm age has a significant effect on EM. However, the results contradict with the research of Indracahya et al. (2017); Wardani and Isbela (2017); Bassiouny (2016); Fajari (2020) which state that firm age does not have a significant effect on EM. The firm age is used to measure the effect of how long the firm operates to its performance. The result shows that the longer the firm age, the more experience in managing and increasing incomes, which causes firms to be easier to engage in EM.

Moreover, leverage does not have a significant effect on EM, the results of this study are in line with the research of Azlina (2010); Chandra et al. (2018); Pagalung (2011) which state that leverage does not have a significant effect on EM. This is because of the security of debt agreements, a firm does not have to rely on EM practices, if a firm has a high level of leverage, EM actions cannot be used as a mechanism for evasion due to the fulfillment of obligations that must be carried out by the firm. However, this study contradicts with the research of Wardani and Isbela (2017); Mahawyahrti and Budiasih (2016); Astuti (2017); Savitri (2014); Agustia (2013) which states that leverage has a significant effect on EM.

The profitability variable does not have a significant effect on EM, this result is in line with the research Agustia and Suryani (2018); Chandra et al. (2018); Prawida (2021); Amertha (2013); Hasty et al. (2017); Purnama (2017) which state that profitability does not have a significant effect on EM. This is because if the profitability is high, the desire of management to manage earnings is decrease, thus if the higher the level of profitability, it does not affect the level of EM (Eva and Yasa, 2020). Fair profitability is a measure of good financial performance. Therefore, firms that have good financial performance do not need to engage in EM. Firms with a high level of profitability show good performance, it makes shareholders, investors and managers will also receive benefits from the performance so that managers are not motivated to take EM actions. However, the results of this study contradict with the research conducted by Setiawan et al., (2016) which states that profitability has a significant effect on EM. The results of this study provide benefits and information for interested parties such as management, investors and potential investors for future decision making by considering the variables used in this study.

\section{CONCLUSIONS}

The results show that firm age and firm size that have a significant effect on EM, while leverage and profitability have no significant effect on EM. Firm age has a significant effect on EM, it indicates that if the firm has been established for a long time, it is assumed that it can generate higher profits than that of a newly established firm. Consequently, the firm will have difficulty in obtaining capital and requires to use its own capital. Firm size has a significant effect on earnings management. It means that the larger firm size, the more likely it is to use debt to meet funding needs than smaller firms. Furthermore, leverage does not have a significant effect on EM, meaning that if a firm with a high level of leverage due to the amount of total debt to total capital will face a high risk of default, as a result the firm is threatened with being unable to fulfill its obligations, however, EM measures cannot be used as a tool to avoid the risk of default. Moreover, profitability has no significant effect on EM. It indicates that firms with large or small levels of profitability have low levels of EM.

In addition, this study has implications for management in continuing the improvement of its performance in monitoring, controlling and increasing supervision of firm activities. Further, the results of this study give better understanding for investors to be more careful in examining the financial reports and growth of performance of the firm. Moreover, it is expected for further research to develop additional variables such as managerial ownership, institutional ownership and dividend policy as well as increasing the years of observation. 


\section{REFERENCES}

Agustia, D. 2013. Pengaruh Faktor Good Corporate Governance, Free Cash Flow, dan Leverage terhadap Manajemen Laba. Jurnal Akuntansi Dan Keuangan, 15(1), 27-42. Https://Doi.Org/10.9744/Jak.15.1.2742.

Agustia, Y. P. and Suryani, E., 2018. Pengaruh Ukuran Perusahaan, Umur Perusahaan, Leverage, dan Profitabilitas Terhadap Manajemen Laba (Studi Pada Perusahaan Pertambangan Yang Terdaftar di Bursa Efek Indonesia Periode 2014-2016). Jurnal ASET (Akuntansi Riset), 10(1), 71-82. Https://Doi. Org/10.17509/Jaset.V10i1.12571

Ajija, S. R., Sari, D. W., Setianto, R. H., \& Primanti, M. R. 2011. Cara Cerdas Menguasai Eviews. Salemba Empat.

Alami, E. 2021. Pengaruh Manajemen Laba Terhadap Underpricing dan Return Saham Setelah Initial Public Offering Di Bursa Efek Indonesia Periode 2015-2019. 02(01), 92-111.

Amertha, I. S. P. 2013. Pengaruh Return On Asset Pada Praktik Manajemen Laba Dengan Moderasi Corporate Governance. E-Jurnal Akuntansi. 4, 373-387.

Astuti, A. Y., Nuraina, E., \& Wijaya, A. L. 2017. Pengaruh Ukuran Perusahaan dan Leverage Terhadap Manajemen Laba. The 9th FIPA: Forum Ilmiah Pendidikan Akuntansi, 5(1), 501-514.

Azlina, N. 2010. Analisis Faktor Yang Mempengaruhi Praktik Manajemen Laba. Pekbis Jurnal, 2(3), 355363.

Badulescu, A., Badulescu, D., Saveanu, T., \& Hatos, R. 2018. The Relationship Between Firm Size and Age, and Its Social Responsibility Actions-Focus on A Developing Country (Romania). Sustainability (Switzerland), 10(3). Https://Doi.Org/10.3390/Su10030805

Bassiouny, S. W. 2016. The Impact of Firm Characteristics on Earnings Management: An Empirical Study on The Listed Firms in Egypt. Www.Jbrmr.Com A Journal of The Academy of Business and Retail Management, 10(Issue 3).

Carolina, M. and Y. 2021. The Impact of Firm Size, Leverage, Firm Age, Media Visibility and Profitability on Sustainability Report Disclosure. Jurnal Keuangan dan Perbankan, 25(1), 36-47. Https://Doi. Org/10.26905/Jkdp.V25i1.4941

Cashmere. 2012. Analysis of Financial Statements (Edition of). PT Raja Grafindo Persada.

Chandra, S. M., \& Djashan, I. A. 2018. Pengaruh Leverage dan Faktor Lainnya Terhadap Manajemen Laba Pada Perusahaan Non Keuangan. Jurnal Bisnis Dan Akuntansi, 20(1), 13-20.

Charoenwong, C. and Jiraporn, P., 2009. Earnings Management To Exceed Thresholds: Evidence From Singapore And Thailand. Journal Of Multinational Financial Management, 19(3), 221-236. Https://Doi. Org/10.1016/J.Mulfin.2008.12.001

CNBC Indonesia. 2020. Harus Diakui Singapura Memang “Raja” Di ASEAN. CNBC Indonesia.

Debnath, P. 2017. Assaying The Impact Of Firm's Growth And Performance On Earnings Management: An Empirical Observation Of Indian Economy. International Journal Of Research In Business Studies And Management, 4(2), 30-40. Https://Doi.Org/10.22259/Ijrbsm.0402003

Dechow, P. M., Sloan, R. G., \& Sweeney, A. P. 1995. Detecting Earnings Management . 70, 193-225.

Desender, K. A., Castro, C. E., \& De León, S. A. E. 2011. Earnings Management And Cultural Values. American Journal Of Economics And Sociology, 70(3), 639-670. Https://Doi.Org/10.1111/J.15367150.2011.00786.X

Dichev, D. B. and I. 1997. Earnings Management To Avoid Earnings Decreases And Losses. Journal Of Accounting And Economics, 24(1), 99-126. Https://Doi.Org/10.1016/S0165-4101(97)00017-7

Ekonomibisnis.Com. 2018. Ekonomi Singapura: Sektor Jasa Dorong PDB Lampaui Target Di Akhir 2017. Ekonomibisnis.Com.

Ekonomibisnis.Com. 2020. Daftar Negara Paling Kompetitif: Singapura Nomor 1, AS Merosot, RI Peringkat Berapa? Ekonomibisnis.Com.

Eva, I. K., \& Yasa, T. 2020. Pengaruh Ukuran Perusahaan, Leverage dan Pada Perusahaan Manufaktur di BEI Tahun 2016-2018. 2(3), 19-32.

Fajari, M. F. 2020. Pengaruh Ukuran Perusahaan, Leverage, Dan Umur Perusahaan Terhadap Manajemen Laba (Studi Empiris Pada Perusahaan Manufaktur Sektor Industri Barang Konsumsi Di Bursa Efek Indonesia Periode 2014 - 2017).

Firnanti, F. 2018. Pengaruh Corporate Governance, dan Faktor-Faktor Lainnya Terhadap Manajemen Laba. Jurnal Bisnis Dan Akuntansi, 19(1), 66-80. Https://Doi.Org/10.34208/Jba.V19i1.66

Gujarati, D. N. dan D. C. P. 2015. Dasar-Dasar Ekonometrika. In Buku 2. Salemba Empat. 
Gunawan, I. K., Darmawan, N. A. S., \& Purnamawati, G. A. 2015. Leverage Terhadap Manajemen Laba Pada Perusahaan Manufaktur Yang Terdaftar Di Bursa Efek Indonesia (BEI). In JIMAT (Jurnal Ilmiah Mahasiswa Akuntansi) Undiksha (Vol. 03, Issue 01). Https://Doi.Org/10.23887/JIMAT.V3I1.5272

Harjito, D. A., \& Martono. 2014. Manajemen Keuangan (Kedua). Ekonisia.

Hasty, A. D., Herawaty, V., \& Trisakti, U. 2017. Pengaruh Struktur Kepemilikan, Leverage, Profitabilitas dan Kebijakan Dividen Terhadap Manajemen Laba dengan Kualitas Audit Sebagai Variabel Moderasi. 17(1), 1-16.

Herlambang, S., \& Darsono. 2015. Pengaruh Good Corporate Governance dan Ukuran Perusahaan Terhadap Manajemen Laba. 4, 426-436.

Hoang, K., \& Vinh, K. N. 2018. Audit Quality, Firm Characteristics and Real Earnings Management: The Case Of Listed Vietnamese Firms. July 2019.

Indracahya, E., \& Faisol, D. A. 2017. The Effect of Good Corporate Governance Elemets, Leverage, Firm Age, Company Size and Profitability on Earning Management (Empirical Study Of Manufacturing Companis Inn BEI 2014-2016). Profita, 10(2), 203-227.

Indriastuti, M. 2012. Analisis Kualitas Auditor dan Corporate Governance Terhadap Manajemen Laba. Eksistansi, IV(2), 1-11.

Jamaludin, I. M., Atti, A., \& Kleden, M. A. 2021. Model Regresi Data Panel Pada Kasus Infeksi Saluran Pernapasan Akut (ISPA) Di Provinsi Nusa Tenggara Timur. ESTIMASI: Journal Of Statistics And Its Application, 2(1), 49-56. Https://Doi.Org/10.20956/Ejsa.V2i1.12504

Jariah, A. 2016. Likuiditas, Leverage, Profitabilitas Pengaruhnya terhadap Nilai Perusahaan Manufaktur di Indonesia Melalui Kebijakan Deviden. Riset Akuntansi Dan Keuangan Indonesia, 1(2), 108-118. Https:// Doi.Org/10.23917/Reaksi.V1i2.2727

Leuz, C., Nanda, D., \& Wysocki, P. D. 2003. Earnings Management and Investor Protection: An International Comparison. Journal of Financial Economics, 69(3), 505-527. Https://Doi.Org/10.1016/S0304405X(03)00121-1

Liu, A. Z. 2015. Can External Monitoring Affect Corporate Financial Reporting and Disclosure? Evidence From Earnings and Expectations Management. Accounting Horizons, 28(3), 529-559. Https://Doi. Org/10.2308/Acch-50771

Mahawyahrti, P.T. and Budiasih, G.N., 2016. Asimetri Informasi, Leverage, dan Ukuran Perusahaan pada Manajemen Laba. Jurnal Ilmiah Akuntansi dan Bisnis, 11(2), pp.100-110. Https://Doi.Org/10.24843/ Jiab.2016.V11.I02.P05

Maryana, M., \& Carolina, Y. 2021. The Impact of Firm Size, Leverage, Firm Age, Media Visibility and Profitability on Sustainability Report Disclosure. Jurnal Keuangan dan Perbankan, 25(1), 36-47. doi:https://doi.org/10.26905/jkdp.v25i1.4941s

Mendes, C. A., Rodrigues, L. L., \& Esteban, L. P. 2012. Evidence of Earnings Management Using Accruals As A Measure Of Accounting Discretion. Tékhne, 10(1), 3-14. Https://Doi.Org/10.1016/S16459911(12)70002-6

Nidheesh, F. 2020. Determinants Of CSR Disclosure: An Evidence From India. Journal Of Indian Business Research, 13(1), 110-133. Https://Doi.Org/10.1108/JIBR-06-2018-0171

Octavia, E. 2017. Implikasi Corporate Governance dan Ukuran Perusahaan Pada Manajemen Laba. Jurnal Akuntansi Multiparadigma, 204, 126-136. Https://Doi.Org/10.18202/Jamal.2017.04.7044

Padli, M. S., Diana, N., \& Afifudin. 2019. Pengaruh Ukuran Perusahaan, Kinerja Keuangan, Financial Leverage dan Manajemen Laba Terhadap Pengungkapan Corporate Social Responsibility Pada Perusahaan Manufaktur Yang Terdaftar Di BEI 2016-2018. E-Jra, 07(10), 119-131.

Pagalung, R. J. dan G. 2011. Corporate Governance, Ukuran Perusahaan dan Leverage Terhadap Manajemen Laba Perusahaan Manufaktur Indonesia. 8(1), 43-54.

Panjaitan, D. K. and Muslih, M. 2019. Manajemen Laba: Ukuran Perusahaan, Kepemilikan Manajerial dan Kompensasi Bonus. Jurnal ASET (Akuntansi Riset), 11(1), pp.1-20. Https://Doi.Org/10.17509/Jaset. V11i1.15726

Permatasari, D. and Wulandari, R.T., 2021. Manajemen Laba dan Faktor yang Mempengaruhinya. Jurnal Akuntansi Indonesia, 10(1), pp.1-19.

Prawida, N. 2021. Leverage, Profitability, Corporate Governance Mecanism and Earning Management: Cases In Manufacturing Company In Indonesia Stock Exchange. 1(1), 35-45.

Purnama, D. 2017. Pengaruh Profitabilitas, Leverage, Ukuran Perusahaan, Kepemilikan Institusional dan Kepemilikan Manajerial Terhadap Manajemen Laba. 3, 1-14.

Rusmin, R. 2010. Auditor Quality and Earnings Management: Singaporean Evidence. Managerial Auditing Journal, 25(7), 618-638. Https://Doi.Org/10.1108/02686901011061324 
Savitri, E. 2014. Analisis Pengaruh Leverage dan Siklus Terhadap Manajemen Laba Pada Perusahaan Real Estate dan Property Yang Terdaftar di Bursa Efek Indonesia. Jurnal Akuntansi, 3(1), 1-18.

Senjani, Y. P. 2013. Manajemen Laba Akrual Dan Riil Sebelum Dan Setelah Adopsi Wajib Ifrs Di Uni Eropa. ETIKONOMI, 12(1).

Setiawan, I., Asnawi, H. F., \& Sofyani, H. 2016. Apakah Ukuran, Profitabilitas, dan Praktik Manajemen Laba Memengaruhi Tingkat Pelaksanaan dan Pelaporan Islamic Social Reporting Pada Perbankan Syariah Di Indonesia? Jurnal Dinamika Akuntansi Dan Bisnis, 3(2), 65-76. Https://Doi.Org/10.24815/ Jdab.V3i2.5387

Solomon, S. J., Bendickson, J. S., Marvel, M. R., Mcdowell, W. C., \& Mahto, R. 2021. Agency Theory and Entrepreneurship: A Cross-Country Analysis. Journal Of Business Research, 122(September 2020), 466-476. Https://Doi.Org/10.1016/J.Jbusres.2020.09.003

Tampubolon, L. D. 2015. Analisis Pengaruh Rasio Keuangan: Likuiditas, Aktivitas dan Leverage Terhadap Penilaian Kinerja Keuangan Studi Empiris: Perusahaan Manufaktur Di Bursa Efek Indonesia Periode 2010 - 2012). Jurnal Keuangan Dan Perbankan, 12(1), 1-12.

Titik, F., \& Putri, M. S. 2014. Pengaruh Kepemilikan Manajerial, Leverage dan Ukuran Perusahaan Terhadap Manajemen Laba Pada Perusahaan Food and Beverage (Studi Pada Perusahaan Food and Beverage Yang Terdaftar di Bursa Efek Indonesia Tahun 2008 - 2013). Jurnal Akuntansi \& Keuangan Universitas Telkom, Vol. 1, No(3), 2-5.

Utari, V.R. and Amin, M.N., 2011. Pengaruh Profitabilitas, Likuiditas, Leverage Keuangan, Ukuran Perusahaan dan Kepemilikan Publik Terhadap Ketepatan Waktu Pelaporan Keuangan Perusahaan Manufaktur Yang Terdaftar di Bursa Efek Indonesia Tahun 2009-2011. Media Riset Akuntansi, Auditing \& Informasi, 11(2), pp.63-88.

Utrero-González, N., \& J. Callado-Muñoz, F. 2016. Do Investors React To Corporate Governance News? An Empirical Analysis For The Spanish Market. BRQ Business Research Quarterly, 19(1), 13-25. Https:// Doi.Org/10.1016/J.Brq.2015.04.002

Wardani, D. K. and Isbela, P. D. 2017. Pengaruh Strategi Bisnis dan Karakteristik Perusahaan Terhadap Manajemen Laba. Jurnal Riset Akuntansi dan Keuangan Fakultas Bisnis UKDW, 13(2), 91-106.

Widyawati, A.A. and Anggraita, V., 2013. Pengaruh Konvergensi, Kompleksitas Akuntansi, dan Probabilitas Kebangkrutan terhadap Timeliness dan Manajemen Laba. Jurnal Akuntansi dan Auditing Indonesia, 17(2), pp.135-155. Https://Doi.Org/10.20885/Jaai.Vol17.Iss2.Art5

Yuliana, R., Anshori, M., \& Alim, M. N. 2015. Real Earnings Management In The Indonesian Sharia Capital Market. Procedia - Social And Behavioral Sciences, 211, 866-873. Https://Doi.Org/10.1016/J. Sbspro.2015.11.114

Zen, S. D., \& Herman, M. 2007. Pengaruh Harga Saham, Umur Perusahaan, dan Rasio Profitabilitas Perusahaan Terhadap Tindakan Perataan Laba Yang Dilakukan Oleh Perusahaan Perbankan Yang Terdaftar di Bursa Efek Jakarta. Jumal Akuntansi \& Manajemen, 2, 57-71. 